\title{
Protozoan parasites in a wastewater treatment plant of Bangladesh
}

\author{
H Khanum $^{1 *}$, S Shanjida Khanam ${ }^{2}$, M Sultana ${ }^{2}$, M H Uddin ${ }^{2}$, R Chandra Dhar ${ }^{1}$, M S Islam ${ }^{2}$ \\ ${ }^{1}$ Parasitology Branch, Department of Zoology, University of Dhaka, Dhaka-1000. ${ }^{2}$ Environmental Microbiology \\ Laboratory, Laboratory Sciences Division, International Centre for Diarrhoeal Disease Research, Bangladesh, G.P.O. \\ Box 128, Dhaka 1000, Bangladesh.
}

\begin{abstract}
Parasitic infection is a global health problem especially in developing countries. Municipal wastewaters always contain cysts of parasitic protozoans at some level. The present study was conducted to detect protozoan parasites in different stages of the treatment plant to check its efficacy. Wastewaters were collected from 3 points of the Pagla Sewage Treatent Plant (PSTP) of Dhaka, Bangladesh, throughout the year, 2007-08 at fortnight intervals. Giardia spp., Entamoeba spp., Entamoeba coli, Endolimax nana, Idoamoeba butschlii and Balantidium coli were detected at different times in different stages of the treatment plant. Among these Giardia and Entamoeba spp. were found most frequently than others. Both the prevalence and dominance of protozoan parasites were reduced gradually with the sampling point of the treatment plant which means that the treatment plant was effective in reducing protozoan parasites but not too effective to eliminate them completely.
\end{abstract}

Key words: Protozoan parasites, Wastewater treatment plant, Dhaka.

\section{Introduction}

Waterborne pathogens can be broadly characterised as parasitic protozoa, helminths, bacteria or viruses. Several protozoan infectious agents have been recognized as waterborne pathogens: Cryptosporidium parvum, Giardia lamblia, Cyclospora, Entamoeba histolytica (Steiner et al., 1997). To date, there have been at least 325 water associated outbreaks of parasitic protozoan disease documented worldwide (Karanis et al. 2007). Most are responsible for opportunistic infections in immunocompromised hosts and belong to the phylum Apicomplexa, with an exception of Microsporidia which are characterised by a unique mode of cellular infection and spore production (Levine et al., 1980). Presently, the role of these emerging protozoan parasites in waterborne infections remains unclear (Marshall et al. 1997). Other protozoa, such as Isospora belli, Cyclospora and Enterocytozoon bieneusi have also been implicated in waterborne outbreaks, although the presence of these parasites in water has rarely been documented (Miegeville et al., 2003). The frequent contamination of surface water by Cryptosporidium and Giardia is well established (; Fayer et al. 2004; Yoder et al., 2004).

As documented, most waterborne protozoan parasites are causative agent for gastroenteritis, diarrhoea and others related to cellular or tissue infections (Stuart et al. 2003 and Roy et al. 2004). C. parvum and G. lamblia are protozoan parasites causing human gastrointestinal illness worldwide, with $C$. parvum reported to cause approximately $2 \%$ and $G$. lamblia between $2 \%-7 \%$ of all diarrhoeal illness in developed countries (Griffiths, 1998). For children under 5 years of age in developing areas and countries, there was a median of 3.2 episods of diarrhoea per childyear. Estimates of mortality revealed that 4.9 children per 1000 per year in developing countries died as a result of diarrhoeal illness in the first 5 years of life. Despite improving trends in mortality rates, diarrhoea accounted for a median of $21 \%$ of all deaths of children under 5 years in developing countries like Bangladesh, India, Brazil, Pakistan, Nigeria and including China, being responsible for 2.5 million deaths per year (Kosek et al., 2003).

Sewage wastewater discharges are worldwide risk factors for the introduction of human protozoan enteropathogens into surface waters. The demand for microbiologically safe reclaimed waters grows exponentially owing to the global demographic rise of the population. Improvements in reclaimed water quality by lowering faecal coliform counts are not a sound solution for human protozoan enteropathogens (Hespanhol, 1997). In urban areas the use of treated wastewater can be considered in irrigation of public parks and recreational centres, sports fields, school gardens, landscaped areas, residential gardens, for commercial uses such as car and glass washing, for decorative purposes such as fountains and waterfalls, for dust control and building projects, to combat fires, in industrial and commercial constructions including bathroom flushing (United States Environmental Protection Agecy, 1992).

The possibility of an outbreak of diseases increases when there is a treatment plant malfunction that enables these parasites to penetrate the treatment processes more easily. Sewage treatment plants have the potential to be a source of contamination to our watershed if the treatment processes employed do not sufficiently treat the effluents before being discharged into nearby waterbody (Lim et al. 2007).

The objective of this research was to identify protozoan parasites in the treatment plant. This study was conducted to provide a quantitative basis for risk assessment studies and development of mitigation strategies, such as improving wastewater treatment efficiency. 


\section{Materials and Methods}

Samples were collected from three points of the Pagla Sewage Treatent Plant (PSTP) which is situated in the eastern part of Dhaka, the capital of Bangladesh. The three sampling points were: Raw Sample from Grit Chamber, Reservoir Sample from Measuring Chamber and Outlet Sample from Outlet Lagoon. A volume of two liters of sample water from each sample site was collected at fortnight intervals during the period of 13 February, 2007 to 3 March, 2008. All the samples were immediately transferred to the laboratory of International Centre for Diarrhoeal Disease Research, Bangladesh (ICDDR,B) for parasitological examination. All the samples were processed by Formol-Ether Concentration Method (Cheesbrough, 2004) following Light Microscopy to observe and identified with the help of Bench aids of WHO (1994), then counted the number of protozoan parasites. However, the method utilized to detect the protozoan parasites does not differentiate between viable and nonviable organisms. Data were analyzed by using Microsoft Excel and SPSS software and the ecological terms considered in this study were according to Margolis et al. (1982) and Bush et al. (1997).

\section{Results and Discussion}

A total of 72 (= 24 samples $\times 3$ sites) samples were collected from PSTP throughout the year. Six protozoan parasites were recognized distinctly by microscopy and these were: Giardia spp., Entamoeba spp., Entamoeba coli, Endolimax nana, Idoamoeba butschlii and
Balantidium coli. Among these waterborne protozoans Giardia spp. and Entamoeba spp. were found in most of the samples throughout the year. Other parasites were comparatively less frequent; especially $B$. coli were very seldom observed (Table-I). The mean intensity, abundance, dominance and standard deviation (SD) were determined andh has been presented in the TableII.

Table-I: Prevalence of protozoan parasites in different sampling point of the PSTP

\begin{tabular}{llll}
\hline \multirow{2}{*}{$\begin{array}{l}\text { Parasitic } \\
\text { Protozoa }\end{array}$} & \multicolumn{3}{c}{ Prit } \\
\cline { 2 - 4 } & Chamber & $\begin{array}{l}\text { Measuring } \\
\text { Chamber }\end{array}$ & $\begin{array}{l}\text { Outlet } \\
\text { Lagoon }\end{array}$ \\
\hline Giardia spp. & 100 & 75 & 20.83 \\
Entamoeba spp. & 83.33 & 83.33 & 8.33 \\
E. coli & 41.67 & 41.67 & 16.67 \\
E. nana & 37.5 & 37.5 & 0 \\
I. butschlii & 54.17 & 33.33 & 4.17 \\
B. coli & 8.33 & 0 & 4.17 \\
\hline
\end{tabular}

The mean intensity, abundance and dominance were found higher for Giardia spp. than all other protozoan parasites detected. B. coli was absent in Measuring Chamber and $E$. nana was absent in the Outlet Lagoon (Table-II). The mean intensity and abundance of identified parasites were very high. The dominance was the highest (44\%) for Giardia spp. all the time and absent for $B$. coli and $E$. nana were absent some times.

Table-II: Mean intensity, abundance and dominance of protozoan parasites in different sampling points.

\begin{tabular}{|c|c|c|c|c|c|}
\hline $\begin{array}{l}\text { Sampling } \\
\text { Site }\end{array}$ & $\begin{array}{l}\text { Parasitic } \\
\text { Protozoa }\end{array}$ & $\begin{array}{c}\text { No. of } \\
\text { contaminated } \\
\text { samples }\end{array}$ & $\begin{array}{l}\text { Mean intensity } \pm S D \\
\text { (No. of parasite/L) }\end{array}$ & $\begin{array}{l}\text { Abundance } \pm \text { SD } \\
\text { (No. of parasite/L) }\end{array}$ & Dominance \\
\hline \multirow{6}{*}{ 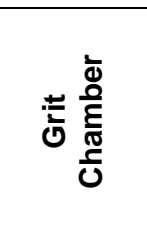 } & Giardia spp. & 24 & $(2.23 \pm 1.44) \times 10^{5}$ & $(2.23 \pm 1.44) \times 10^{5}$ & $44.03 \%$ \\
\hline & Entamoeba spp. & 20 & $(1.40 \pm 0.75) \times 10^{5}$ & $(1.17 \pm 0.87) \times 10^{5}$ & $23.05 \%$ \\
\hline & E. coli & 10 & $(1.40 \pm 0.70) \times 10^{5}$ & $(5.83 \pm 8.30) \times 10^{4}$ & $11.52 \%$ \\
\hline & E. nana & 9 & $(1.39 \pm 1.11) \times 10^{5}$ & $(5.21 \pm 9.50) \times 10^{4}$ & $10.29 \%$ \\
\hline & I. butschlii & 13 & $(9.23 \pm 5.34) \times 10^{4}$ & $(5.00 \pm 6.08) \times 10^{4}$ & $9.88 \%$ \\
\hline & B. coli & 2 & $(7.50 \pm 3.54) \times 10^{4}$ & $(6.25 \pm 22.4) \times 10^{3}$ & $1.23 \%$ \\
\hline \multirow{6}{*}{ 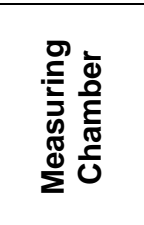 } & Giardia spp. & 18 & $(1.14 \pm 0.78) \times 10^{5}$ & $(8.54 \pm 8.40) \times 10^{4}$ & $33.88 \%$ \\
\hline & Entamoeba spp. & 20 & $(6.25 \pm 4.98) \times 10^{4}$ & $(5.21 \pm 6.34) \times 10^{4}$ & $20.66 \%$ \\
\hline & E. coli & 10 & $(9.00 \pm 4.62) \times 10^{4}$ & $(3.75 \pm 5.16) \times 10^{4}$ & $14.88 \%$ \\
\hline & E. nana & 9 & $(6.67 \pm 2.50) \times 10^{4}$ & $(2.50 \pm 3.61) \times 10^{4}$ & $9.92 \%$ \\
\hline & I. butschlii & 8 & $(1.56 \pm 1.24) \times 10^{5}$ & $(5.21 \pm 10.2) \times 10^{4}$ & $20.66 \%$ \\
\hline & B. coli & 0 & 0 & 0 & $0.00 \%$ \\
\hline \multirow{6}{*}{ 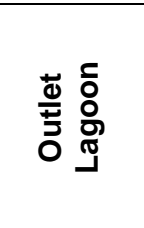 } & Giardia spp. & 5 & $(7.00 \pm 2.74) \times 10^{4}$ & $(1.46 \pm 3.12) \times 10^{4}$ & $38.89 \%$ \\
\hline & Entamoeba spp. & 2 & $(1.00 \pm 0.00) \times 10^{5}$ & $(8.33 \pm 28.2) \times 10^{3}$ & $22.22 \%$ \\
\hline & E. coli & 4 & $(6.25 \pm 2.50) \times 10^{4}$ & $(1.04 \pm 2.54) \times 10^{4}$ & $27.78 \%$ \\
\hline & E. nana & 0 & 0 & 0 & $0.00 \%$ \\
\hline & I. butschlii & 1 & $(5.00 \pm 0.00) \times 10^{4}$ & $(2.08 \pm 10.2) \times 10^{3}$ & $5.56 \%$ \\
\hline & B. coli & 1 & $(5.00 \pm 0.00) \times 10^{4}$ & $(2.08 \pm 10.2) \times 10^{3}$ & $5.56 \%$ \\
\hline
\end{tabular}

Both the prevalence and dominance of protozoan parasites were reduced gradually which means that the treatment plant was effective in reducing protozoan parasites. However, the plant could not eliminate them. The number of protozoan parasites has been demonstrated by the Figure-I, II and III. A number of assessments on the efficiency of wastewater treatment plants by activated sludge have done by using the bacterial population as the indicator organism. 


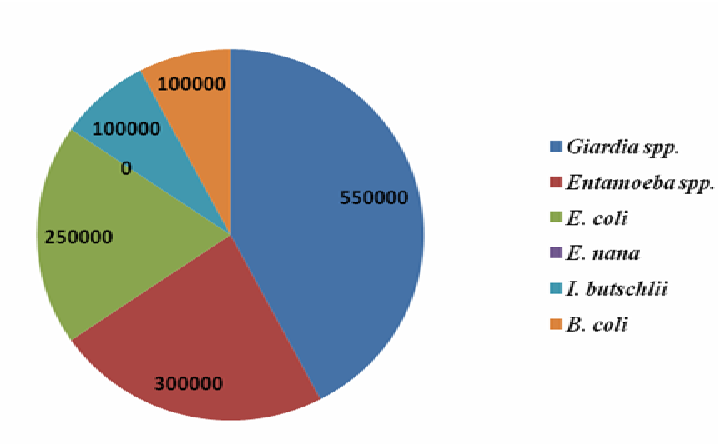

Figure-I. The number of protozoan parasites in Grit Chamber (Cysts/Litre) of the PSTP.

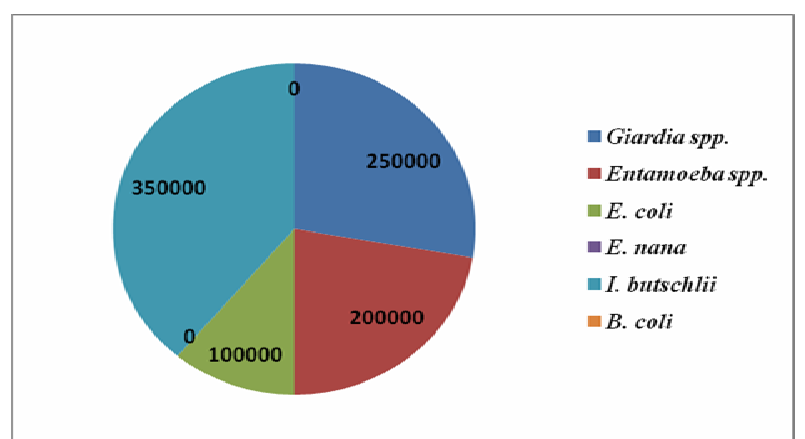

Figure-II. The number of protozoan parasites in Measuring Chamber (Cysts/Litre) of the PSTP.

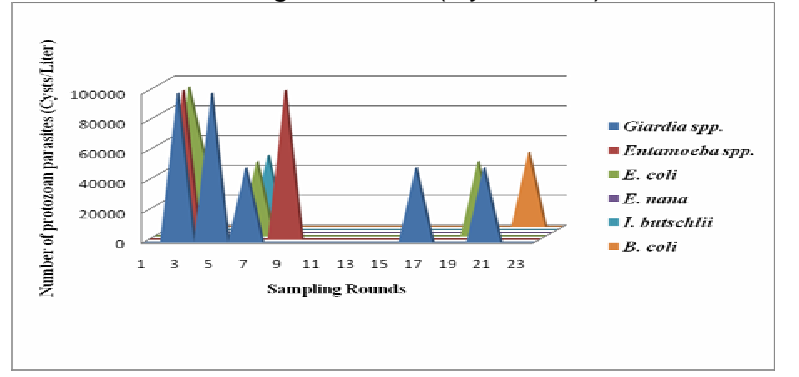

Figure-III. The number of protozoan parasites in Outlet Lagoon (Cysts/Litre) of the PSTP.

Environmental conditions make human beings vulnerable to parasites, and thousands of people in developing countries live under inadequate conditions without proper water supplies and sanitation. Waterborne diseases are common due to the shortage of drinking water, and conditions of storage and manipulation of foods contaminated by human and animal excrement (World Health Organization, 1991). The importance of monitoring and controlling the quality of residual water for reuse in irrigation and aquaculture has been highlighted by the World Health Organization (1989). The contamination of water bodies by discharged treated wastewater may contain emerging pathogens such as $C$. parvum oocysts and G. lamblia cysts (Cutolo et al., 2006).
No strong correlation was found for any indicatorpathogen combination. Public health is not adequately protected by simple monitoring schemes based on detection of a single indicator (Harwood et al. 2005). The study revealed the occurrence and quantity of various parasitic protozoans in different stages of the treatment of the PSTP. The PSTP covers about $18 \%$ of the city population. No previous record concerning sewage treatment plant has been found and hence the present study seems to be very significant to assess the health risk of the Dhaka city. All the identified parasites are endemic in this country where Giardia and Entamoeba spp. were found most frequently than others. Raw and treated wastewater samples were analyzed for parasites and an array of parasites were detected, namely Giardia sp., E. histolyticaldispar, E. coli, Ascaris sp., Enterobius vermicularis, Taenia sp. by Lim et al. (2007) in Malaysia.

In the present study the count of parasitic protozoans' cysts varied per litre which is similar to the findings of Lim et al. (2007). Other studies conducted in Sweden, Norway and Canada also report the constant detection of Giardia in sewage (Ottoson et al. 2005). But there was a reduction in the number of cysts $E$. nana which may be due to the treatment of the plant. The results of the present study suggest that the treatment of wastewater promoted a reduction of infectious cysts of parasites but it could not remove all protozoan parasites properly, reflecting a constant risk of infection.

\section{Conclusion}

From the study a better understanding of the abundant protozoan parasites and the role of treatment process in removal of these parasites was obtained. As the treated sewage water from the PSTP is directly discharged into Buriganga River which embanks Dhaka city, the present study was designed to assess the Plant's role in meeting the public health criteria. The study discloses the occurrence of a variety of protozoan parasites, which represents a certain range of health risk existing in Dhaka city. The study also provides recommendations to improve the performance of the treatment plants in terms of parasites elimination.

\section{References}

Bush, A. O., Lafferty, K. D., Lotz, J. M. \& Shostak, A. W., 1997. Parasitology Meets Ecology On Its Own Terms: Margolis Et Al. Revised. J. Parasitol. 83(4): 575-583.

Cheesbrough, M., 2004. District Laboratory Practice in Tropical Countries, Part I. Cambridge University Press.UK. 454 pp. 
Cutolo, S.A., Matte, M.H. \& Rocha, A.A., (2006). Monitoring of parasitological contamination in treated wastewater from activated sludge system. Management of Environmental Quality: An International Journal 17(1): 43-56.

Fayer, R., 2004. Cryptosporidium: a waterborne zoonotic parasite. Vet. Parasitol. 126: 37-56.

Griffiths, J.K., 1998. Human Cryptosporidiosis: Epidemiology, transmission, clinical disease, treatment and diagnosis. In: Water pollution control. A Guide to the Use of Water Quality Management Principles, (Eds. Helmer, R. and Hespanhol, I.). E. \& F.N. Spon, London on behalf of UNESCO, WHO and UNEP.

Hespanhol, I., 1997. Wastewater as a resource. In: Water pollution control. A Guide to the Use of Water Quality Management Principles, (Eds. Helmer, R. and Hespanhol, I. E. \& F.N. Spon, London on behalf of UNESCO, WHO and UNEP.

Harwood, V. J., Levine, A. D., Scott, T. M., Chivukula, V., Lukasik, J., Farrah S. R. \& Rose, J. B., 2005. Validity of the Indicator Organism Paradigm for Pathogen Reduction in Reclaimed Water and Public Health Protection. Appl. Environ. Microbiol. 71(6): 3163-3170.

Karanis, P., Kourenti, C. \& Smith, H., 2007. Waterborne transmission of protozoan parasites: A worldwide review of outbreaks and lessons learnt. Journal of Water and Health 5(1): 1-38.

Kosek, M., Bern, C. and Guerrant, R.L., 2003. The global burden of diarrhoeal disease, as estimated from studies published between 1992 and 2000. Bulletin of the World Health Organization 81: 197-204.

Levine, N.D., Corliss, J.O., Cox, F.E., Deroux, G., Grain, J., Honigberg, B.M., Leedale, G.F., Loeblich III, A.R., Lom, J., Lynn, D., Merinfeld, E.G., Page, F.C., Poljansky, G., Sprague, V., Vavra, J. \& Wallace, F.G., 1980. A newly revised classification of the protozoa. J. Protozool. 27: 103-117.

Lim, Y.A.L., Hafiz, W. W.I. \& Nissapatorn, V., 2007. Reduction of Cryptosporidium and Giardia by sewage treatment processes. Tropical Biomedicine 24(1): 95-104.

Margolis, L., Esch, G.W., Holmes, J.C., Kuris, A.M. \& Schad, G.A., 1982. The use of ecological term in parasitology. (Report of an Ad hoc Committee of the American Society of Parasitology). J. Parasitol. 68(1): 131-133.

Marshall, M.M., Naumovitz, D., Ortega, Y. \& Sterling, C.R., 1997. Waterborne Protozoan pathogens. Clin. Microbiol. Rev. 10: 67-85.
Miegeville, M., Koubi, V., Dan, L.C., Barbier, J.P. \& Cam, P.D., 2003. Cyclospora cayetaensis et sa pr' esence en milieu hydrique a' Hanoi (Vietnam). Etude dans l' environment (eaux de forage, lacs et rivie'res). Bull. Soc. Pathol. Exot. 96: 149-152.

Lee, R. \& Jones, J.L., 2004. Epidemiologic and environmental investigation of recreational water outbreak caused by two genotypes of Cryptosporidium parvum in Ohio in 2000. Am. J. Trop. Med. Hyg. 71(5): 582-589.

Ottoson, J., 2005. Comparative analysis of pathogen occurrence in wastewater-management strategies for barrier function and microbial control. TRITA-LWR PhD Thesis: $1021 \mathrm{pp}$.

Roy, S.L., Delong, S.M., Stenzel, S.A., Shiferaw, B., Roberts, J.M., Khalakdina, A., Marcus, R., Segler, S.D., Shah, D.D., Thomas, S., Vugia, D.J., Zansky, S.M., Dietz, V. \& Beach, M.J., 2004. Risk factors for sporadic Cryptosporidiosis among immunocompetent persons in the United States from 1999 to 2001. J. Clin. Microbiol. 42: 2944-2951.

Steiner, T.S., Thielman, N.M. \& Guerrant, R.L., 1997. Protozoal agents: what are the dangers for the public water supplies? Annu. Rev. Med. 48: 329-340.

Stuart, J.M., Orr, H.J., Warburton, F.G., Jeyakanth, S., Pugh, C., Morris, I., Sarangi, J. and Nichols, G., 2003. Risk factors for sporadic Giardiasis: a case-control study in southwestern England. Emerg. Infect. Dis. 9: 229-233.

United States Environmental Protection Agency., 1992. Guidelines for Water Reuse, United States Environmental Protection Agecy, Washington, DC, EPA/625/R-92/004.

World Health Organization., 1991. Environmental health in urban development. Techincal Report Series, No. 807, World Health Organization, Geneva. World Health Organization., (1989). Health guidelines for the use of wastewater in agriculture and aquaculture. Techincal Report Series, No. 778, World Health Organization, Geneva.

World Health Organization., 1994. Bench Aids for Diagnosis of Intestinal Parasites. Geneva: World Health Organization.

Yoder, J.S., Blackburn, B.G., Craun, G.F., Hill, V., Levy, D.A., Chen, N., Lee, S.H., Calderon, R.L. \& Beach, M.J., 2004. Surveillance for waterborne-disease outbreaks associated with recreational water, United States, 2001-2002. MMWR Surveill. Summ. 22(53): 1-22. 